\title{
BRAND IMAGE AND CUSTOMER SATISFACTION IN MOBILE PHONE MARKET: STUDY BASED ON CUSTOMERS IN KANDY DISTRICT
}

\author{
Dunuwille V.M ${ }^{1}$ and Pathmini M.G.S ${ }^{2}$ \\ Dept. of Business Management, Faculty of Management Studies, Rajarata University of Sri Lanka \\ vishakadunuwilla024@gmail.com ${ }^{1}$ andthikavi76@gmail.com²
}

\begin{abstract}
In a competitive and Brand conscious market, building Brand Image of Mobile Phones is challenging task. In this context, this study aims to examine the relationship between Brand Image and Customer Satisfaction in Mobile Phone Market among Customers in Kandy District in Sri Lanka. Based on reviewed literature, it was found that the Brand Image was strongly related to Customer Satisfaction. Accordingly, four independent variables were identified as major dimensions of the Brand Image; Perceived Quality (PQ), Brand Loyalty (BL), Brand Awareness (BW) and Brand Association (BAs). This study was deductive, an exploratory type. The population of the study consisted in Mobile Phone users of Kandy District. 110 respondents were selected as the sample representing four main cities in the Kandy District; Katugastota, Pilimathalawa, Peradeniya, Akurana using the convenience sampling method. Questionnaire method was administrated to collect primary data. Descriptive statistics and inferential statistics techniques were applied to analyze the data. The hypotheses have been tested using Pearson correlation, regression and multiple regression analysis. It was indicated that Brand Awareness as the most significant factor related to Customer Satisfaction. Results showed that there is a significant impact of all independent variables (PQ, BL, BW, BA) on customer satisfaction in Mobile Phone Market. Recommendations were provided to marketers and managers in mobile phone industry to achieve high Customer Satisfaction through building strong Brand Image.
\end{abstract}

Keywords: Brand Image, Customer Satisfaction, Mobile Phone Market.

\section{INTRODUCTION}

In a competitive and dynamic business environment, the brand image of a product is very important to determine its market position. Brand image is the consumer's impression about the brand's physical characteristics, its performance, the functional benefits, the kind of people who use the product, the emotions and Journal of Business Studies associations it develops, and the imagery or symbolic meanings, it generates. Furthermore, Brands are introducing each and every day leads to anever ending competition. At this juncture, making customers' brand loyalty is emerging as a big challenge but it is the need for getting a better market share and profitability. Even though it can only be done by making customer 
satisfy and developing a good image in their mind . Customer loyalty and customer satisfaction are also widely accepted phenomena for all the companies, which is applied as a marketing benchmark for the performance of the company (Bennett and Rundle -Thiele, 2004 cited by Neupane, 2015). In order to attract new customers and retain the existing customers for any organization, the brand image is very important because of the fact that the customers always seek for branded products in this current competitive environment. Thus, companies are facing intense challenges in enhancing customer satisfaction and brand image. Sri Lankan mobile phone providers also as a growing industry must be given higher attention to the customer satisfaction since mobile phone users' preferences are frequently changing. So, mobile phone customers in Sri Lanka are frequently switching their brand preference to other competitive brands aiming to get high value and satisfaction. Today, numerous brands are offered in the mobile market and therefore it has created broad space to choose variety brands to fulfill the customer satisfaction. With this situation, evaluating customer's satisfaction is crucial for mobile phone providers to facilitate the best offering to the target market. Therefore, brand image plays a strategic role in the mobile phone market and also managers can gain competitive advantages. So, this study aims to evaluate the impact of Brand Image on determining the Customer Satisfaction in mobile phone market giving special attention to customers in Kandy District.

\section{RESEARCH PROBLEM}

In the Sri Lankan mobile market, there is huge competition with growing brands. Therefore, most of the marketers are giving substantive effort on establishing the brand, and building customer satisfaction. As a result, a number of brands have introduced in the market for the purpose building long term profitable relationship as well as brand equity. The best approach to customer retention is delivering a high level of customer satisfaction that result in, strong customer loyalty. In Sri Lanka, There are more mobile phone brands walking down into the market. According to Sri Lanka Mobile Handset Market Review, (2014) indicates that the Sri Lanka mobile handset market recorded sales of over 0.76 million in 1Q (January-March) 2014.In the overall Sri Lankan mobile handset market divided 2 types. There are feature phone and smart phone. Both feature phone and Smart phone are several brands in the mobile market; Nokia, Micro max, E-Tel, Blackberry, Motorola, Samsung and etc. Even though, few major players dominate by capturing a significant market share. Under the category of feature phone, Nokia as the leading mobile phone vendors $(26.2 \%$ of market share) in Q1-2014 compared to 23.8\% market share in Q4-2013. Micro max has retained the $2^{\text {nd }}$ place $(18.3 \%$ of market share) while Micro max had a $21.4 \%$ market share in Q4-2013. With 11.4\% of market 
share E-Tel beat Samsung to claim the $3^{\text {rd }}$ position in this market. But Samsung occupied $3^{\text {rd }}$ spot in Q4-2013 with a 12\% market share. It showed that an improvement of the position ( $2^{\text {nd }}$ spot back) in Q3-2013. Samsung emerged as the leader in the smart phone segment with $27.7 \%$ share in 1Q- 2014, followed by Huawei with $18.9 \%$. E-Tel occupied third place with $13.9 \%$ share during the same period. According to these figures, it is obvious that mobile phone brands have faced a rigid competition at maintaining their customers' satisfaction. Sothis study aims to find out, "How does Brand Image influence Customer Satisfaction of the mobile phone market in Sri Lanka"

\section{RESEARCH OBJECTIVES}

The primary objective of the study was to an analyze the impact of brand image on customer satisfaction in the mobile phone market in the Kandy district in Sri Lanka. The specific objectives ware; to explain the nature and level of customer satisfaction and brand image in this market; to identify the brand image factors which influence to the mobile phone customer satisfaction; to find out mostly influencing brand image factor on the mobile phone customer satisfaction; and provide recommendations to improve customer satisfaction through brand image in mobile phone market in Sri Lanka.

\section{LITERATURE REVIEW 4.1 Customer Satisfaction}

According to Hansenmaek and Albinsson (2004), customer satisfaction and retention become an important factor for an organization since they tends to give a big advantage for companies. Oliver (1980) reveals that consumer is formed by expectations referring to the performance or quality of a product. Thus, customer satisfaction emphasis the degree to which customers is happy with the use of products that are provided to them by the companies. To maintain the customer satisfaction, companies must keep in mind their needs and wants and supply them outstanding products and services. So, business can move on to the upper level of advantage by achieving customer satisfaction in a competitive market. Customers make their expectation and perception about the brand by means of positive word of mouth, selling and promotion activities with market strategies. It seems a possibility to spread bad word of mouth, if any customers experienced with dissatisfaction on the product what they consumed(Ahmed, 2014). According to (Edward C. M. et al, 2003 cited in Samantaray, 2014) customer satisfaction is a key indicator of good marketing practice since customer satisfaction helps in the future success and profitability of the company. Also, Kurt Matzlera, in 2004 (cited in Samantaray, 2014) explained that, customer satisfaction as key driver of the financial performance. It is argued that satisfaction leads to increased loyalty, reduced price elasticity, increased cross-buying, and positive word of mouth. According to Vavra (2002), customers can 
obtain satisfaction from overall product, particular performance of the product, representatives of the company, various transactions like presentation of sales, delivery of products, complaints handling; and post-purchase relationships generated by a company with their Customers (cited in Neupane, 2015).

\subsection{Brand Image}

"A Brand defined as a term, design, name, symbol or any other features that distinguish one company's product to the others" (American Marketing Association, 2013). Brand image is a unique set of associations in the mind of customers regarding what a brand stand for and the implied promises the brand makes . According to Keller, K. (2003) cited in Horaga, Ozora, \& Stiefanie,
(2012) "Brand Image is the set of beliefs, ideas and impression that a person holds regarding to an object" According to Horaga, et.al., (2012), brand Image is the interpretation of the customers about all the indications from products, services, and communication of brand. Kotler, K. (2003) cited by, Horaga, et.al., (2012), states that brand image as the customer's mind reflection of the image and trust of brands. According to Sliburyte \& Bivainiene, (2008), brand image was identified as an element of brand equity. Hsiung,(2011) regarded four dimensions in measuring brand image in catering businesses, as brand value, brand characteristics and brand association. To measure brand image of cosmetics products used benefits were: functional, social, symbolic, experiential and

Table 4.1: Measurements of Brand Image

\begin{tabular}{|l|l|}
\hline Author & Measurements \\
\hline Hsiung,(2011) & Brand Value, Brand Characteristics and Brand Association \\
\hline $\begin{array}{l}\text { Stephen, Maznah, } \\
\text { Nabsiah, Ishak, \& } \\
\text { Amran, (2007). }\end{array}$ & $\begin{array}{l}\text { Functional, Social, Symbolic, Experiential, Appearance enhances } \\
\text { Benefits }\end{array}$ \\
\hline Fianto, (2014) & Saliency, Reputation, Familiarity and Trustworthy \\
\hline $\begin{array}{l}\text { Horaga, Ozora, \& } \\
\text { Stiefanie, (2012) }\end{array}$ & $\begin{array}{l}\text { Strength of brand association, the favorability of brand association } \\
\text { and the uniqueness of brand association }\end{array}$ \\
\hline $\begin{array}{l}\text { Ahmad \& } \\
\text { Sherwani1, (2015) }\end{array}$ & $\begin{array}{l}\text { Perceived Quality, Brand Loyalty, Brand Awareness, Brand } \\
\text { Association }\end{array}$ \\
\hline $\begin{array}{l}\text { Petrauskaite, } \\
\text { (2014) (Brand } \\
\text { equity) }\end{array}$ & $\begin{array}{l}\text { Perceived Quality, Brand Loyalty, Brand Awareness, Brand } \\
\text { Association }\end{array}$ \\
\hline \hline
\end{tabular}


appearance enhances. According to Fianto (2014) regarded four indicators of measuring brand image; saliency, reputation, familiarity and trustworthy. Further, Oraga, et.al., (2012), revealed the measures of brand image through the strength of brand association, favorability of brand association and the uniqueness of brand association. When consider the brand equity; perceived quality, brand loyalty, brand awareness and brand association were identified as the measures. Petrauskaite, (2014) used four dimensions to measure brand image in footwear market which were perceived quality, brand loyalty, brand association and brand awareness.

\subsection{Brand Image and Customer Satisfaction}

GU, (2005) suggested that customer satisfaction and brand characteristics presented significant relationship (cited in Hsiung, 2011). Also, it found that the positive relationship between brand image and customer satisfaction (Horaga, et.al.,
2012; Neupane, 2015).Stephen, Maznah, Nabsiah, Ishak, \& Amran, (2007)found four image benefits; experiential, social, functional and appearance which has significant effects on satisfaction. They discovered that symbolic benefit has a negative effect on satisfaction and loyalty. Beatty (1999) found only social and functional benefits to be positively related to satisfaction (cited by Stephen, Maznah, Nabsiah, Ishak, \& Amran, 2007). Hsiung (2011)shows the requirement of modern customer-oriented marketing theory to take customer satisfaction into account when making decisions and establishing brand image. Fianto, (2014)shows poor perception of brand image on customer's preferences in making purchasing behavior. Positive brand image contributes to enhance customer loyalty and it has great roles in building a strong brand image of a company. Therefore, brand image is essential for companies to gain lifetime customer loyalty which leads to gear up organizational efficiency (Hess and Story, 2005 cited in Neupane, 2015). Malik, Ghafoor \& Iqbal, (2012) found improvements in brand image resulted in increased customer satisfaction and improved brand loyalty. Yang (2002) proposed that customer satisfaction referred to the pleasant attitude when a customer

Table 4.2: Relationship between Brand Image and Customer Satisfaction

\begin{tabular}{|l|l|l|}
\hline Poor & Moderate & Strong positive \\
\hline Fianto, (2014) & $\begin{array}{l}\text { Malik, Ghafoor2, \& } \\
\text { Iqbal( 2012) }\end{array}$ & $\begin{array}{l}\text { Horaga, Ozora, \& Stiefanie } \\
(2012)\end{array}$ \\
\hline $\begin{array}{l}\text { Stephen, Maznah, Nabsiah, } \\
\text { Ishak, \& Amran, (2007) }\end{array}$ & Hsiung (2011) \\
\hline & & $\begin{array}{l}\text { Stephen, Maznah, Nabsiah, } \\
\text { Ishak, \& Amran, (2007) }\end{array}$ \\
\hline
\end{tabular}


accepting certain deal or service; and, customer satisfaction and brand value appeared notably positive relation (cited by Hsiung ,2011).The literature summarized in table 4.2, on the relationship between brand image and customer satisfaction shows there is strong positive relationship between brand image and customer satisfaction.

\section{CONCEPTUAL MODEL}

The four main areas were analyzed, brand awareness, brand loyalty, perceived quality and brand associations (Aaker, D. 1991; Keller, K. 2003 cited in Petrauskaite,2014), in order to understand which subdivision/s is/are most influential to create and maintain mobile phone brand images.

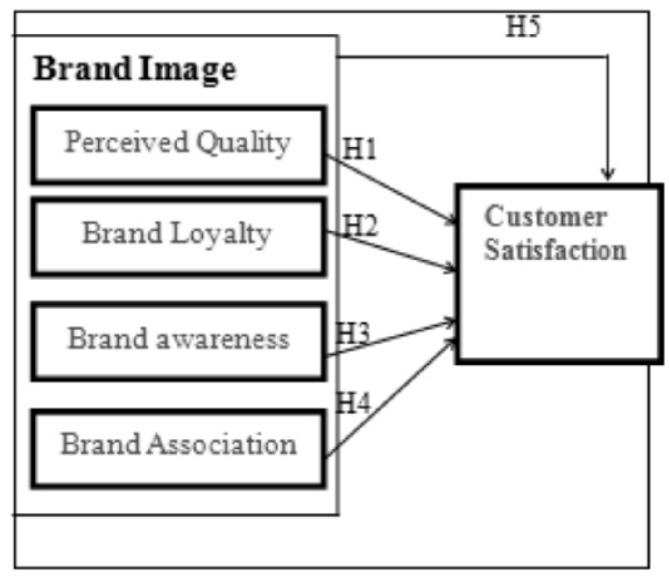

Figure 5.1 Conceptual Model

\section{HYPOTHESES}

$\mathbf{H}_{1}$ : There is a significant relationship between Perceived Quality and customer satisfaction.

$\mathbf{H}_{2}$ : There is a significant relationship between brand loyalty and customer satisfaction

$\mathbf{H}_{3}$ : There is a significant relationship between brand awareness and customer satisfaction

$\mathbf{H}_{4}$ : There is a significant relationship between brand association and customer satisfaction

$\mathbf{H}_{5}$ : There is a significant relationship between brand image and customer satisfaction.

$\mathbf{H}_{6}$ : Brand loyalty is the most significant factor to determine the customer satisfaction

\section{METHODOLOGY}

The deductive method applied for the study because of the study conducted based on existing theories and published literature on the brand image and customer satisfaction.

The target population of this study was the population living in Kandy District 2012. According to reports of the Department of Census and Statistics in 2012, population of Kandy District was approximately 1,375,382.Among them,110 respondents were selected as the sample representing four main cities; Katugastota, Pilima thalawa, Peradeniya, Akurana using the convenience sampling method. KMO and Bartlett's test was used to test the adequacy of sample size. Both primary and secondary data were considered for the study and secondary data such as Department of Census and Statistics reports, web sites and related journals was used in this research. Primary data which is the most important part of the study was collected via a structured questionnaire using a survey of 110 respondents. The data gathering instrument were a closed ended questionnaire. And it was distributed to the 
customers within the sample. Out of 110 questionnaires that have been distributed; 100 respondents were responded and 10 questionnaires were not completed. Questionnaire was consisted of three parts. Part 01; background information, Part 02; brand Image and it checks perceived quality, brand loyalty, brand awareness, and brand association. Part 03; customer satisfaction under the measures of customer expectation, customer value, positive opinion about brand and manufacture and overall satisfaction. The questions administrated with 5 - points Likert scale from 5 to 1 representing strongly agree to strongly disagree. The analysis of the data was performed applying SPSS 21 version and data was coded by using the SPSS data editor. The data gathered was analyzed with the support of descriptive statistics; (mean, standard deviation) and inferential statistics (ANOVA test, Pearson coefficient of correlation, regression).

\section{R E S U L T S A N D DISCUSSION}

According to figures indicated in table 8.1, 55 percent respondents were males and 45 percent were females which mean majority were male participants. When considering the age level, major participants were between 25-35 years old $(41 \%)$, the second was $16-25$ years old $(37 \%)$. The highest number of participants was reported in an income range of Rs.20000- Rs.40000 (37\%) the second was less than Rs.20000 (21\%). Also, it was found that the majority (49\%) respondents were using the Nokia brand, 18\% respondents Samsung brand. Also, it is apparent that over 75 percent of customers have already used more than one mobile phone brand.

Table 8.1: Description of Respondents

\begin{tabular}{|l|l|c|c|}
\hline Variable & Category & Frequency & Valid Present \\
\hline Gender & Male & 55 & 55 \\
& Female & 45 & 45 \\
\hline Age & $16-25$ & 37 & 37 \\
& $25-35$ & 41 & 41 \\
& $35-45$ & 22 & 22 \\
\hline \multirow{3}{*}{ Income } & Dependent & 20 & 20 \\
& Less than 20000 & 21 & 21 \\
& $20000-40000$ & 37 & 37 \\
& $40000-60000$ & 19 & 19 \\
& More than 60000 & 3 & 3 \\
\hline \multirow{3}{*}{ Education Level } & O/L & 32 & 32 \\
& A/L & 34 & 34 \\
& Diploma & 19 & 19 \\
& Undergraduate & 9 & 9 \\
& Graduate & 5 & 5 \\
\hline \hline
\end{tabular}




\begin{tabular}{|l|l|c|c|}
\hline \multirow{5}{*}{ Brand } & Nokia & 49 & 49 \\
& LG & 8 & 8 \\
& Sony & 7 & 7 \\
& Micromax & 15 & 15 \\
& Samsung & 18 & 18 \\
& Other & 3 & 3 \\
\hline \multirow{3}{*}{ No of Brand used } & & 25 & 25 \\
& One Brand & 28 & 28 \\
& Two Brand & 28 & 28 \\
& Three Brand & 12 & 12 \\
\hline & Four Brand & 7 & 7 \\
\hline
\end{tabular}

Source: Survey Data, 2015

\subsection{Reliability Test}

The reliability of a measure is an indication of the stability and consistency with which the instrument measures the concept and helps to assess the goodness of a measure. (Sekaran, U. 2007). Reliability results of the test are presented in table 8.2 and accordingly all the variables are accepted under the condition of Cronbach's alpha with reflect to the Sekaran (2007).

KMO and Bartlett's Test is one of measurement to check the validity of data whether the sample is adequate. The sampleis adequate if the value $\mathrm{KMO}$ is

Table 8.2: Summary of the Reliability

\begin{tabular}{|l|c|c|}
\hline \multicolumn{1}{|c|}{ Mimensions } & $\begin{array}{c}\text { No of } \\
\text { items }\end{array}$ & $\begin{array}{c}\text { Alpha } \\
\text { Values }\end{array}$ \\
\hline Perceived Quality & 5 & 0.844 \\
\hline Brand Loyalty & 4 & 0.889 \\
\hline Brand Awareness & 5 & 0.788 \\
\hline Brand Association & 3 & 0.786 \\
\hline $\begin{array}{l}\text { Customer } \\
\text { Satisfaction }\end{array}$ & 7 & 0.891 \\
\hline
\end{tabular}

Source: Survey results, 2015 Journal of Business Studies greater than 0.5 (Field 2000; 466) cited by . The table 8.3 shows that KMO is 0.836 which is the sample is adequate and significant value of Bartlett's Test is 0.000 .

\subsection{Descriptive statistics}

In this study Descriptive statistics usually involved measures of central tendency (mean) and measures of dispersion

Table 8.3: KMO and Bartlett's Test

\begin{tabular}{|c|c|c|}
\hline \multicolumn{2}{|c|}{$\begin{array}{l}\text { Kaiser-Meyer-Olkin Measure } \\
\text { of Sampling Adequacy. }\end{array}$} & 0.836 \\
\hline \multirow{3}{*}{$\begin{array}{l}\text { Bartlett's } \\
\text { Test of } \\
\text { Sphericity }\end{array}$} & $\begin{array}{l}\text { Approx. Chi- } \\
\text { Square }\end{array}$ & 1956.554 \\
\hline & $\mathrm{Df}$ & 276 \\
\hline & Sig. & 0 \\
\hline
\end{tabular}

Source: Survey Data, 2015

(variance, standard deviation) etc. The table 8.4 presented mean, std. deviation and variance to describe the level of said variables.

According to the statistical figures in table 8.4 ,customer satisfaction showed in the 
Table 8.4: Descriptive Statistics of Dimension of Brand Image and Customer Satisfaction

\begin{tabular}{|l|l|l|l|}
\hline Dimension & Mean & Standard Deviation (SD) & Variance \\
\hline Perceived Quality & 3.718 & 0.804 & 0.647 \\
\hline Brand Loyalty & 3.072 & 1.138 & 1.296 \\
\hline Brand Awareness & 3.388 & 0.802 & 0.645 \\
\hline Brand Association & 3.473 & 1.032 & 1.067 \\
\hline Customer Satisfaction & 3.438 & 0.971 & 0.943 \\
\hline
\end{tabular}

Source: Survey results, 2015

level of moderate with substantial SD. Perceived quality indicate higher level. Brand loyalty, brand awareness, and brand association are showed the level of moderate with considerable SD.

\subsection{Test of Hypotheses}

According to the result indicated in the table 8.5 , all the dimensions of brand image have a strong positive correlation with customer satisfaction. Customer satisfaction can be increased by increasing brand image through brand awareness, and brand loyalty. According to the results indicated in the table 8.5, all the hypotheses can be accepted.

\subsection{Regression Analysis}

According to the result indicated in the table $8,6, R^{2}$ and adjusted $R^{2}$ values of 0.780 and 0.771 respectively, both indicated that there was a high degree of goodness of fit of the regression model. It means that independent variables for the test have ability to explain

Table 8.6: Model Summary

\begin{tabular}{|l|c|c|c|}
\hline $\begin{array}{l}\text { Mode } \\
\mathbf{l}\end{array}$ & $\mathbf{R}$ & $\begin{array}{c}\mathbf{R} \\
\text { Square }\end{array}$ & $\begin{array}{c}\text { Adjusted R } \\
\text { Square }\end{array}$ \\
\hline 1 & $.883^{\mathrm{3}}$ & 0.78 & 0.771 \\
\hline
\end{tabular}

a. Predictors (constant), BA, PQ, BL, BW

Source: Survey results, 2015

Table 8.5: Summary result of hypotheses

\begin{tabular}{|l|l|c|c|}
\hline Hypothesis & Statement & $\begin{array}{l}\text { Pearson } \\
\text { Correlations }\end{array}$ & $\begin{array}{l}\text { Sig. (2- } \\
\text { tailed) }\end{array}$ \\
\hline H1 & $\begin{array}{l}\text { There is a positive relationship between } \\
\text { perceived quality and customer satisfaction. }\end{array}$ & $.607^{* *}$ & .000 \\
\hline H2 & $\begin{array}{l}\text { There is a positive relationship between brand } \\
\text { loyalty and customer satisfaction }\end{array}$ & $.734^{* *}$ & .000 \\
\hline H3 & $\begin{array}{l}\text { There is a positive relationship between brand } \\
\text { awareness and customer satisfaction }\end{array}$ & $.845^{* * *}$ & .000 \\
\hline H4 & $\begin{array}{l}\text { There is a positive relationship between brand } \\
\text { association and customer satisfaction }\end{array}$ & $.702 * *$ & .000 \\
\hline H5 & $\begin{array}{l}\text { There is a positive relationship between overall } \\
\text { brand image and customer satisfaction }\end{array}$ & $.859 * *$ & .000 \\
\hline
\end{tabular}

Source: Survey results, 2015

Journal of Business Studies 
78percent variation of the dependent variable. customer satisfaction because standardized coefficient of beta was 0.593 and significant

Table 8.7: ANOVA

\begin{tabular}{|l|l|r|r|r|r|r|}
\hline \multicolumn{2}{|l|}{ Model } & \multicolumn{1}{c|}{$\begin{array}{c}\text { Sum of } \\
\text { Squares }\end{array}$} & \multicolumn{1}{c|}{ Df } & Mean Square & F & \multicolumn{1}{c|}{ Sig. } \\
\hline \multirow{3}{*}{1} & Regression & 72.85 & 4 & 18.213 & 84.204 & $.000^{b}$ \\
\cline { 2 - 7 } & Residual & 20.548 & 95 & 0.216 & & \\
\cline { 2 - 7 } & Total & 93.398 & 99 & & & \\
\hline
\end{tabular}

a. Dependent Variable: CS

b. Predictors: (Constant), BA, PQ, BL, BW Source: Survey results, 2015

The F test was 84.204with the significance ('Sig') of 0.000 . This meant that the Probability of these results occurred by chance was less than 0.05. Therefore, a significant relationship was presented between brand image and customer satisfaction.

\subsection{Multiple Linear Regressions}

The data in table 8.8 shows that the regression coefficient for brand awareness and brand association are all statistically significant. Additionally, found that brand awareness has the greatest impact on the value was $0.000(p<0.05)$. The data also indicates that brand association is the second most important element driving customer satisfaction ( $\mathrm{B}=0.283$ ). Thus both of $\mathrm{H}_{3}, \mathrm{H}_{4}$ hypotheses are accepted. Perceived quality is not showed an impact on customer satisfaction because the coefficient of beta was 0.000 with larger significant value 0.995. Therefore, perceived quality of mobile phones was not impact to determine the customer satisfaction. According to the results, $\mathrm{H}_{6}$ is rejected(brand loyalty is the most significant factor to determine the

Table 8.8: Multiple Regression results of factors affecting to Customer Satisfaction

\begin{tabular}{|c|c|c|c|c|c|c|}
\hline \multirow{2}{*}{\multicolumn{2}{|c|}{ Model }} & \multicolumn{2}{|c|}{$\begin{array}{l}\text { Unstandardized } \\
\text { Coefficients }\end{array}$} & \multirow{3}{*}{$\begin{array}{c}\text { Standardized } \\
\text { Coefficients } \\
\text { Beta } \\
\end{array}$} & \multirow[t]{2}{*}{$\mathbf{T}$} & \multirow[t]{2}{*}{ Sig. } \\
\hline & & B & Std. Error & & & \\
\hline \multirow{5}{*}{1} & (Constant) & -0.203 & 0.241 & & -0.841 & 0.402 \\
\hline & PQ & 0 & 0.085 & 0.00 & -0.006 & 0.995 \\
\hline & $\mathrm{BL}$ & 0.094 & 0.066 & 0.11 & 1.414 & 0.161 \\
\hline & BW & 0.717 & 0.113 & 0.593 & 6.342 & 0.000 \\
\hline & BA & 0.266 & 0.059 & 0.283 & 4.510 & 0.000 \\
\hline
\end{tabular}

a. Dependent Variable: CS

Source: Survey results, 2015 
customer satisfaction), because the most significant variable was brand awareness $($ Beta $=0.593$ with sig 0.000)

\section{CONCLUSION}

Main objectives of this study were to find out the level of customer satisfaction of mobile phones in Sri Lanka and analyze its relationship with the factors of brand image. As per the results, it shown the level of customer satisfaction is in the moderate level. This conclusion is supported by previous literature Karunarathna \& Nismi, (2011). Perceived quality, brand loyalty, brand awareness, and brand association are also positively relatedto customer satisfaction. There was a strong positive relationship between brand loyalty and customer satisfaction. This means that the brand loyalty and customer satisfaction are precisely related. According to Yoo, (2000) brand loyalty has the power to impact on customer decision to purchase the same product or brand and decline to shift to competitors' brands (cited in Ahmad \& Sherwani1, 2015). Brand awareness and customer satisfaction were two variables that had strong positive relationship. This means that the two variables are precisely related and that, as value of one variable was increased. This conclusion is supported by Bilal \& Malik, (2014). There is positive relationship between perceived quality and customer satisfaction in mobile phones. It was proved by Kumar, (2014). Strong positive relationship existed between Brand Association and customer satisfaction. This conclusion is also supported by previous literature as Kumar, (2014) found positive relationship between brand association and customer satisfaction. The most significant brand image factor affect to the customer satisfaction of mobile phone market was brand awareness and brand loyalty. Because of awareness has a high correlation value with less than 0.05 significant levels when compare the other independent variables. Ultimately as a whole on the statistics, customer satisfaction can be increased by increasing brand image on brand awareness, and brand loyalty in the mobile phone market in Sri Lanka.

Same time, the research findings reveals marketing managers should concentrate their effort primarily on brand loyalty as an construct of brand image because it can contribute positively to the firms market. Also, in the highly competitive mobile handset industry, they should work to retain consumer loyalty and gain repeated business. Brand loyalty has several important strategic benefits to the firms, such as gaining high market share and new customers, supporting brand extensions, reducing marketing costs, and strengthening brand to the competitive threats. Further, as per the research results brand awareness, contributing moderately to build the brand image. So, brand image could be changed for the better by successful advertising and introducing simple logo or symbol to identify customers easily their preferred brand. This would suggest that Mobile 
phone products ought to pay attention to their advertising in the future and think about whom their target group for each advertisement is and this could also affect customer satisfaction.

\section{L I M I TAT I O NSAND FURTHER RESEARCH AREAS}

The research study to measure brand image and customer satisfaction in the mobile handset market is limited to Kandy District only, so there is a scope to study brand image and customer satisfaction of other regional markets of Sri Lanka to avoid the significant regional gaps. Furthermore, the restriction of using convenience sampling techniques has indicated that the outcomes of this research cannot be generalized.There were some potential limitations of the study happened on the way. In this research the sample was reduce to 100 and selected few brand of the mobile phone branded in market.This research is limited to one city of Sri Lanka and could not be demonstrative of all citizens of Sri Lanka and also it limited small sample size. The follow up researches may increase the sample size and collect data from various locations of Sri Lanka. This study mainly focused on the brand image in the mobile market with customer satisfaction. Therefore, other researchers can apply these variables to various consumer products in the market.

\section{REFERENCES}

Ahmad, F., \& Sherwani1, N. U. (2015). An Empirical Study on the effect of Brand Equity of Mobile Phones on Customer Satisfaction. International Journal of Marketing Studies.

Ahmed, Z. (2014). Effect of brand trust and customer satisfaction on brand loyalty in Bahawalpur. Journal of Sociological Research.

Bilal, A., \& Malik, F. M. (2014). Impact Of

Brand Equity \& Brand Awareness on Customer's Satisfaction. International Journal of Modern Management \& Foresight.

Bravo R, Montaner T, \& Pina J M. (2012). Corporate Brand Image of Financial Institutions. Journal of Product \& Management.

Fianto, A. Y. (2014). The Influence of Brand Image on Purchase Behaviour Through Brand Trust. Business Management and Strategy.

Ghafoor, M. M., Iqbal, H. K., Murtaza, F., \& Tariq, U. (2012). Imapct of Customer Satisfaction and Brand Image on Brand Loyalty. Progress in Business Innovation \& Technology Management.

Hansemark O.C.and Albinsson M., (2004), Customer satisfaction and Retention; the experience of individual employees, managing service quality, 14 (1), 40-57.

Horaga, A. E., Ozora, O., \& Stiefanie. (2012). The Factors of Brand Image 
which Influence Customer Loyalty of J.CO.

Hsiung, L. C. (2011). A study on the relations between the brand image and customer satisfaction in catering businesses. African Journal of Business Management.

Hsiung, L. C. (2011). A study on the relations between the brand image and customer satisfaction in catering businesses. African Journal of Business Management.

Karunarathna, A. C., \& Nismi, M. N. (n.d.). The impact of Service Quality on Customer Satisfaction.

Kumar , A. (2014). Brand Equity and Customer Satisfaction - A Study of Lg Television In Mysore District. International Journal of Management Research \& Review.

Malik, M. E., Ghafoor, M. M., \& Iqbal, H. K. (2012). Impact of Brand Image, Service Quality and price on customer satisfaction in Pakistan Telecommuni cation sector. Internat ional Journal of Business and Social Science.

Neupane, R. (2015). The Effects of Brand Image on Customer Satisfaction and Loyalty Intention in Retail Super Market Chain Uk. International Journal of Social Sciences and Management .

Oliver L.R. (1980), "A cognitive model of the antecedents and consequences of satisfaction decision. " Journal of Marketing Research, Vol. 7,: 460469.
Petrauskaite, E. (2014). Effect of Brand Image on Consumer Purchase Behaviour: International Footwear Market Comparison.

Riyath, M. I., \& Musthafa, S. L. (2013).Factors Affecting Mobile phone Purchase in the greater Accra Region of Ghana. International journal of marketing studies.

Samantaray, A. (2014). Factors Influencing Customer Satisfaction: With Special Reference to Soap. International Journal in Physical \& Applied Sciences.

Sekaran, U. (2007). Research Methods for Business. New York.

Sliburyte, L., \& Bivainiene, L. (2008).

The Brand Image as an Element of Brand Equity. Socialiniai tyrimai / Social Research.

Stephen, S. L., Maznah, O. W., Nabsiah, W. A., Ishak, I., \& Amran, H. (2007). THE Effect of Brand Image on Overall Satisfaction And Loyalty Intention in The Context of Color Cosmetics. Asian Academy of Management Journal. 